\title{
Implementation Of Cultural Tourism Development Program Based On Local Wisdom In Bedulu Village Regency Of Gianyar Bali
}

\author{
Ni Ketut Arismayanti1*, NM. Ariani², IK. Suwena ${ }^{3}$, \\ 1,2,3 Udayana University
}

\section{A R T I C L E I N F O}

Article history:

Received 15 March 2018

Received in revised form 16 May 2018

Accepted 30 June2018

Available online 28 August 2018

Keywords:

Development, cultural tourism, local wisdom, tourist village.

\begin{abstract}
A B S T R A C T
Implementation of cultural tourism development program in Bedulu village aims to strengthen community empowerment through the development of cultural tourism in accordance with the vision and mission aimed at strengthening village management system; Increasing public participation in tourism activities and development; Improve selffinancing and self-help communities and to improve the welfare of the community as well as increasing the original income of Gianyar regency. The implementation approach model includes: 1) Participatory Rural Appraisal (PRA) model; 2) Model of Entrepreneurship Capacity Building (ECB); and 3) Transfer Technology Model (TT). Implementation of the program include: 1) Identification of tourism potential at Tourism Attraction Goa Gajah Temple, Relief of Yeh Pulu, Samuan Tiga Temple, and Tegallinggah Cliff Temple; 2) Focus Group Discussion (FGD) with relevant stakeholders on potential and strategic issues of cultural tourism development based on local wisdom in Bedulu Village; 3) Training of Packaging Cultural Tour Packages in Bedulu Village; 4) Technical Training for Tour Guide in Bedulu Village; 5) Making of Guide Book; 6) Making Bedouin Tourism Brochure; 7) Practical English Training in Bedulu Village; 8) Homestay Management Training in Bedulu Village; 9) Culinary Development Training of Bedulu Village; 10) Village Tourism Management in Bedulu Village. The outputs generated in these community service activities include: guide books; Brochures in English and Japanese; Tutorial on website management; Marketing of tourist attraction located in Bedulu Village through website, Instagram social media, and video uploaded on YouTube; Capacity building and knowledge as well as community capacity with various training provided.
\end{abstract}

\footnotetext{
${ }^{*}$ Corresponding author.

E-mail addresses: arismayanti_pariwisata@unud.ac.id (NK. Arismayanti), ayukariani97@yahoo.com (NM. Ariani), suwena_ketut@yahoo.co.id (IK. Suwena),
} 


\section{Introduction}

Bedulu Village is one part of Blahbatuh District, Gianyar Regency with an area of 457 Hectares. Bedulu village is located at coordinates $8^{\circ} 31^{\prime} 4^{\prime \prime}$ South Latitude and $115^{\circ} 17$; 56.6" East Longitude with an altitude of about 150 meters above sea level. The existence of Bedulu Village is located in the center of Bali Island and is very close and easily accessible from all directions, both provincial, district, and sub-district towns. The distance from Bedulu Village to the City of Bali Province (Denpasar City) is about $25 \mathrm{~km}$ and can be reached within a period of about 35 minutes. While the distance to the City District (Gianyar City) is $5 \mathrm{~km}$ and can be reached within a period of 15 minutes, while the City District (Blahbatuh) is $4 \mathrm{~km}$ and can be reached within 10 minutes.

Bedulu village is located stretching from west to east and its western and eastern sides are limited and flanked by two major rivers, namely Petanu River and Pakerisan River. While in the middle flows small rivers and creeks, namely Jurang River and Batuh River. Bedulu village is bordered by Pejeng Village, Bitera Village, Pejeng Kelod Village, Buruan Village, and Kemenuh Village. In addition, the spring source of Bedulu Village also comes from Goa Gajah (Elevent Cave) Temple, Beji Samuantiga, Dedari Bedulu Temple, Sudamala Wanayu water spring, and Tegaling Tegalinggah Temple. Bedulu Village has the other natural resources in the form of stone quarry stone used for Balinese style building materials along the Petanu River.

In addition to its natural potential, Bedulu Village also holds cultural potential associated with Bedulu village history in the book of Kertagama Country written by Mpu Prapanca in 1365 AD. "Bedulu" is derived from the word "Badahulu" meaning "place of leader, prince or king". Badahulu is the palace of the last ancient Balinese king named Astasura Ratna Bhumi Banten which was subdued by Majapahit in an attack under the leadership of Gajah Mada in $1343 \mathrm{AD}$. The tradition that is still growing and can be used as a hint that Bedulu is now a result of the development of the ancient Balinese Badahulu is the existence of religious ceremonial traditions in Pura Jero Agung Bedulu, such as Damar Kurung, Sidhakarya Ceremony, Nuwur / Nyineb / Nyimpen Ratu Jawa Ceremony, There is Pelinggih Ratu Jawa and there are Lod Jero rice field complex. In addition, around the Bedulu village found many archaeological remains as evidence of traces of historical past. Even traditions that are still protected and well maintained by the Bedulu society reflect that Bedulu formerly played an important role in the context and dynamics of social life and culture of the past.

In addition, there is "Lwa Gajah" can be identified as Goa Gajah which means "water coming out of the statue of Elephant" which can still be witnessed until now. In Goa Gajah there is a statue of a shower located in front of the entrance of the cave that was once found around the pond by the Department of Antiquities in 1952. The existence of Goa Gajah Temple as the remains of the X century, XI, Samuan Tiga Temple as the monumental remains of the unification of sects in Bali In the XI century. Jero Agung Temple remains the XI-XIV century as a proof of the history of the Bedulu Village that has played a significant role in the life of Balinese people in the past. As an ancient village, Bedulu has bequeathed the cultural remains of archaeological remains containing cultural, social, economic, educational and technological values. These cultural heritage or heritage can be used as identity identifiers and can also be a tourist attraction that will eventually bring in foreign exchange that is expected to meet the economic needs of the community.

Cultural tourism development efforts in the future need to be done by exploiting the potential that exists, especially tourism potential and cultural potential. In the development of tourism is basically planning is necessary to prevent physical, socio-cultural impact and other negative impacts that can occur due to tourism development in the area. In the development of tourism should pay attention to the carrying capacity of the environment for tourism development can be sustainable and the type of tourism developed in accordance with the potential and environmental conditions of the area.

But in fact the development of tourism in Bedulu village, on the one hand has not been able to give a significant economic contribution to the community as well as improving the environmental quality as well as cultural preservation on the existing tourist attraction. On the other hand, tourists who come to visit only limited to see the sights and make the documentation around the tourist attraction without any explanation about the objects or activities undertaken by farmers in the fields, increased knowledge or tourist experience that can be obtained by involving tourists directly in various activities Tours.

\section{Methods}

Taking into account the outcome of the activity, the method that will be used to overcome the problems in Bedulu village can be classified into two, namely the data of tourism potential of the region and the community empowerment program. To achieve the outcome target, it is done by the following method: 1) Data collection through field survey; 2) Empowerment program through counseling, training, 
and mentoring, i.e. meeting periodically between the assistant and the target group. The approach model includes: (1) participatory rural appraisal (PRA) model; (2) entrepreneurship capacity building model (ECB); And (3) technology transfer model (TT). Targeted community groups with potential and problems are:

Table 1. Profiles of Target Group with Potentials and Problems

\begin{tabular}{|c|c|c|c|}
\hline No & Target Group & Potential & Problems \\
\hline & $\begin{array}{l}\text { The } \\
\text { community group } \\
\text { that will be assigned } \\
\text { to manage the } \\
\text { tourist attraction in } \\
\text { Bedulu Village. }\end{array}$ & $\begin{array}{l}\text { As a manager and } \\
\text { implementer of cultural } \\
\text { packaged cultural tour } \\
\text { packages activities. } \\
\text { Having knowledge and } \\
\text { able to interpret all the } \\
\text { potential tourism and culture } \\
\text { in Bedulu village as a cultural- } \\
\text { based rural tourism attraction. }\end{array}$ & $\begin{array}{l}\text { 1. Not yet the formation of managers } \\
\text { and implementers of cultural- } \\
\text { based rural packaging packages. } \\
\text { 2. There is no uniform } \\
\text { understanding of the meaning of } \\
\text { tourism and cultural potential in } \\
\text { Bedulu Village. } \\
\text { 3. Do not have a guidebook as a } \\
\text { source of information about } \\
\text { cultural uniqueness in Bedulu } \\
\text { Village as a source of information } \\
\text { for local guide. }\end{array}$ \\
\hline
\end{tabular}
Generation / Sekeha of cultural-based rural tour Teruna Teruni packages.

(STT).

The PKK team

Family members in 15 households who are homestay owners.

Tourism stakeholders such as: BPW (travel agent), tour guide and hotel and villa businessman around Ubud. used as a package of culturalbased rural tour packages.

Home with unique Balinese style suitable to be a place to stay for tourists.

Market Cultural Rural Tour Packages in Bedulu Village.
1. Weak human resource capabilities in tourism, especially related to packing tour packages and tour guides.

2. Not yet the establishment or organization of local guide in Bedulu Village

1. Cannot present the typical culinary Village Bedulu to meet the tastes of tourists.

2. Existing culinary has not been included in the cultural-based rural package component.
Tourism stakeholders are less familiar with the cultural-based rural tourism packages available in Bedulu Village.

The indicator of achievement program in Bedulu Village there are:

1) The improvement of rural tourism management system based on culture in Bedulu Village, Blahbatuh District by forming Tourism Management Agency in Bedulu Village which is tasked to manage, market and operate cultural-based rural tourism packages which have been prepared through management training for human resources in Bedulu Village, Blahbatuh District continuously.

2) Increased public participation in the development of cultural tourism in Bedulu Village, Blahbatuh District. Community participation in this case involves the involvement and participation in the management and implementation of operational activities of rural tourism packages based on the 
culture that offer to tourists. The community is expected to be involved as a local guide for cultural tourism packages based on culture, homestay for tourists, culinary provision, tracking arrangement, and selling Bedulu village handicrafts, arts and carvings.

3) The increase of self-financing and self-supporting community to realize the vision and mission of Bedulu Village and Gianyar Regency Government in developing cultural tourism to be more known by tourists.

4) There is an additional income / income received by the target group from the development of cultural tourism in Bedulu Village. So that the concrete outcomes to be achieved in the program is the creation of cultural-based village tour packages package in Bedulu Village with its various components that are ready to be marketed in the form of brochures, the availability of local guides Bedulu Village and the realization of the Tour Guide on tourism potential and the uniqueness of Bedulu Village as a source of information for Local guide and tourists.

Method of implementation of activity in Bedulu Village to overcome the problem is done through several stages as follows: 1) The steps in the form of the program to be implemented to achieve the expected results in Bedulu Village are, a) Strengthening Bedulu Village Management Institution, b) Create rural tour packages activities in the form of brochures to be offered to tourists that include activities to see, something to do, something to buy and something to learn, which culture-based rural tourism packages are all started and finish in Bedulu Village, c) Identification and preparation of cultural tourism attractions that will be visited by tourists in Bedulu Village, d) Preparing an Information Handbook on the cultural potential of the Bedulu Village, both tangible and intangible, e) Preparation of houses as a place to stay for tourists (homestay), f) Increasing the competence of human resources in the field of tourism services for the target group, including the ability of guiding techniques and English proficiency, g) Creating a distribution channel marketing (distribution channel) for cultural-based rural tourism packages in Bedulu Village. And 2) The methods used in empowering the target groups are: data collection methods through field surveys, and empowerment programs through counseling, training, and mentoring, i.e.: regular meetings between assistants and target groups. Model approaches include: (1) Participatory rural appraisal (PRA) model; (2) Model of entrepreneurship capacity building (ECB); and (3) Transfer technology model (TT).

\section{Results and Discussion}

\section{Overview of Bedulu Village}

Bedulu Village is one part of Blahbatuh District, Gianyar Regency, located at coordinates 8o 31, 4 "South Latitude and 115o 17, 56.6" East Longitude, located about 150 meters from sea level. The existence of Bedulu Village is in the middle of the island of Bali and is very close and easily accessible from all directions, either from Provincial, District, or District. Bedulu village is located stretching from West to East and on both western and eastern sides is bounded and flanked by two major rivers, namely Petanu River in the west and Pekerisan River on the East. In middle, the flows of small rivers and creeks, namely Jurang River and Batuh River.

The economic structure of Bedulu Village is still an agrarian style that focuses on agriculture / fisheries sector. Some sectors that are an economic base and stand out in addition to the agricultural sector are trade, home industry, and processing and tourism sector. The existence of the tourism sector in Bedulu village is the second mainstay after the agricultural sector because many people are involved in the tourism world considering the existence of craftsmen engaged in the field of handy craft, in the form of stone carvings and sculptures.

\section{History of Bedulu Village}

Bedulu Village name etymologically estimated comes from the word Badahulu contained in the book Kertagama Country written by Mpu Prapanca in 1365 AD. In the third stanza of XIV stanza mentioned that the subordinate state in the east of Java, among others Bali with the important State of Badahulu and Lwa Gajah (Slamet Mulljono, 1953; Pegeoud, 1960; in Monument Besa Bedulu 2013/2014).

The word Badahulu consists of the word Bada which means place, and Hulu which means leader, prince, or king. Thus, Badahulu as mentioned in the State of Kertagama means the place of leaders or kings (royal palace). In its development, the word Badahulu became Bedulu which etymologically can be interpreted as an important place at the time of Ancient Bali as a place of the leaders or the royal palace in controlling the government of Bali. Badahulu is the palace of the last King of Bali Kuna, namely Astasura Ratna Bhumi Banten which was subdued by Majapahit in an attack under the leadership of Gajah Mada in 1343 AD. 
While Lwa Gajah can be defined as the current Elephant Cave, Lwa means water; Elephant means Elephant. So Lwa Gajah means water that comes out from the statue of the Elephant, as can be seen now from Gua Elephant in the form of a shower statue located in front of the entrance of the cave. The cave was found around the pond by the Archeological Service in 1952.

Historical data reinforced by the folklore associated with the attacks of Gajah Mada and the life of Dukuh Kendangan, and the existence of a tradition that is still developing in the life of Bedulu society until today. In the story Dukuh Kedangan told that before Patih Gajah Mada attack Bedulu, first stop to Padukuhan and asks for advice and strategizes the attack to succeed, because it is known that the King of Bali is very strong. With his various tricks, Gajah Mada finally succeeded in conquering the King of Bali and editing the daughter of Dukuh Kedangan named Ni Luh Sekarini. It seems that the history of life of Gajah Mada and Ni Luh Sekarini is what is enshrined in Yeh Pulu Relief in Bedulu Village.

The tradition is still growing and can be used as a hint, that Bedulu is now the result of the development of Bedahulu ancient Balinese with the existence of traditions of religious ceremonies in Jro Agung Bedulu Temple. At every ceremony in PuraJero Agung Temple which celebrate on Full moon on June (Purnama sasih Asada), always done things that seem to have a certain meaning, such as:

\section{Damar Kurung}

Damar brackets are lights made of coconut placed in a basket. Damar brackets are installed during the ceremony at Jero Agung Temple. Damar parenthesis is hung on each penjor is plugged in front of the temple or temple brackets. The light emitted by the brackets of parentheses as a harbinger for the Javanese community (Majapahit) that the people of Bali (Badahulu) are conducting a ceremony at Jero Agung Temple which is the palace of the Ancient Balinese King (Astasura Ratna Bhumi Banten) subdivided by Majapahit).

2. Sidhakarya ceremony

Sidhakarya ritual at Jro Agung Temple uses chicken meat that is lost in the cage (be beware). Ceremonies that use chicken meat are very rare in other communities in Bali.

3. Nuwur / Nyineb / Nyimpen Ratu Jawa Ceremony

The Nuwur / Nyineb / Nyimpen Ratu Jawa ceremony is the last ceremony. The Queen of Java is Majapahit. In Jero Agung Temple area there is with a building called Pelinggih Ratu Jawa. While in the south Jero Agung Temple there is a rice field area called Lod Jero (south palace).

In addition to the tradition of the ceremony, around Bedulu village found many archaeological remains as evidence of traces of history of the past. Even up to now the tradition and remains are protected and well maintained by the Bedulu community which reflects that Bedulu used to play an important role in the context and dynamics of social life and culture of the past. This is related to the existence of Goa Gajah Temple as the hermitage remained around the X and XI centuries; Samuan Tiga Temple as a relic of monumental unification of sects in Bali in the XI century; And Jero Agung Temple as the XI century remained until the XIV century as a proof of the history of Bedulu village which is very instrumental in the life of Balinese people.

As an ancient village, Bedulu Village has bequeathed the cultural remains of archaeological objects laden with cultural, social, economic, educational and technological values. These cultural heritage or heritage can be used as identity identifiers and can be a tourist attraction that will eventually bring in revenues that can increase the income of Bedulu Village community.

\section{Tourism Potential in Bedulu Village}

Bedulu village has potential and cultural potential that is very potential and interesting to be developed for tourism. The number of tourist visits to Bedulu Village from year to year began to increase. The tourism potential in the village Bedulu, namely:

1) Travel Attractions Goa Gajah Temple

Goa Gajah tourist attraction is located in Banjar Goa, Bedulu Village, Blahbatuh District, Gianyar Regency. Goa Gajah tourist attraction is astonomically located at the coordinate point $8^{\circ} 31^{\prime} 24.38$ "S, 115 - 17'13.76" E. This tourist attraction has a very strategic location, circled by rice fields and beautiful canyon Petanu River, and is in the tourist route of Denpasar - Tampaksiring - Lake Batur / Kintamani. Attraction is $\pm 5 \mathrm{Km}$ distance from Ubud Tourism Area. The attractions of Pura Goa Gajah reflect the reign of several kings, among others: Sri Dharmawangsa Wardhana Marakartapangkajastano Tunggadewa (1022 AD), King Anak Wingsu (1053 AD) and Paduka Sri Mahaguru (1324 AD). In the Kertagama book written by Mpu Prapanca during the reign of King Hayam Wuruk on the Majapahit Era, mentioned Goa Gajah is located in Bedulu village as the residence of the Bodadyaksa. When it was also mentioned the term Kunjarakunjapada which means "Kunjara Dormitory", ie "Kunjara" in Sanskrit means "Elephant". This hostel is Rsi Agastya hostel located in Mysore, South India. In those days there were many wild 
elephants living in the dormitory and the term was most likely to be reminiscent of the existence of an existing Kunjarakunjapada dormitory in India.

2) Relief Attractions of Yeh Pulu

Yeh Pulu Relief tourist attraction is located in Banjar Batulumbang, Bedulu Village, Blahbatuh District, Gianyar Regency. Yeh Pulu Relief tourist attraction is astronically located at the coordinate point 8o31'47.1936 "S, 115o17'34.8648" E. The tourism attractions has a distance of 8.4 km from Gianyar City which can be reached about 15 minutes from the intersection area Four Bedulu Village and then head south and enter the village road, it will appear a guide to the tourist attraction Relief of Yeh Pulu. The name Yeh Pulu comes from two vocabularies, namely "Yeh" which has the meaning of "Water" and "Pulu" which means "Gentong". The name Yeh Pulu is taken from a barrel that stands to the west of the relief, right in the center of the purified water source. At Yeh Pulu tourist attraction there is a very unique ancient relief. Therefore, this tourist attraction is often referred to as Relief Yeh Pulu. Relief of Yeh Pulu is a historical tourist attraction in the form of ancient carvings on rock walls. This relief has a length of approximately 25 meters with a height of about 2 meters and is estimated to be built in the 14th century or the 15th. This relief was first discovered by a courtier of the Kingdom of Ubud in 1925. History of Yeh Pulu reliefs located in this tourist site tells about the history of the life of the ancient Balinese people during the Bedahulu Kingdom. Not only the reliefs are beautifully engraved on the walls, the hole indented into the hermit is also in the attraction of this tour. It is said that the hole is used for the hermitage of King Bedahulu, before he lost the battle against the kingdom of Majapahit in 1343. This tourist attraction is accomplished by passing a well-groomed trail with unspoiled natural beauty. This tourist attraction also provides parking facilities, toilets, public baths, homestay, cafes, art shop and local tour guide services.

3) Tourist Attractions of Samuan Tiga Temple

Tourist attraction of Samuan Tiga Temple is located in Banjar Pekandelan, Bedulu Village, Blahbatuh District, Gianyar Regency. Samuan Tiga Temple Cultural Reserve is astronomically located at the coordinate point $8^{\circ} 31^{\prime} 25.83^{\prime \prime} \mathrm{S}, 115^{\circ} 17^{\prime} 41.81^{\prime \prime E}$. This temple is a place of worship for Hindus in Bali. The temple building is very unique and features Balinese architecture. The history of the founding of Samuan Tiga Temple comes from written data such as inscriptions, prakempa, purana, or babad which until now many found. The name Samuan Tiga comes from the word "Samua" meaning "meeting, union, sangkep" and "Tiga" meaning "three or pointing at number three". So Samuan Tiga means meeting or unification of three things or deliberations of triangle (Soebandi, 1983: 67).

Based on the description of tattoos Tatwa Siwa Purana mentioned that Pura Samuan Tiga was built during the reign of king Candrasangka. The writing of Lontar Tatwa Siwa Purana and these other lontar may be an attempt to rewrite various traditions of local historical beliefs and other things. The possibility is very large because if traced from the chronology of the kings in Bali, there is no king named Candrasangka, but there is a Candrabhayasingha Warmadewa mentioned in the preserves are now stored in Sakenan Temple Manukaya Tampaksiring which contains the making of sacred lakes / baths called Tirta at Hampul Water (Sutterheim, 1929: 68-69).

When Prabu Candrasangka as mentioned in the tattoos of Tatwa Siwa Purana or another name of the king of Candrasangka Warmadewa as mentioned in the inscription of Manukaya which dates to 962 $\mathrm{AD}$, it can be said that Pura Samuan Tiga was built contemporaneously with Pura Tirta Empul, which is about X century. Pura Samuan Tiga in the X century may be in the context of the application of the religious conception of the Old Kuna period, as said R. Goris, that every kingdom must have three main temples, namely Pura Gunung, Pura Penataran and Pura Segara. The Tirta Empul Temple as its mountain temple and Samuan Tiga Temple as temple of upgrading, which is temple which is in the center of kingdom. Experts estimate the center of government during the period of Bali Kuna around the Bedulu village because many found archaeological remains (statues, hermitage), even lasted until the Majapahit Kingdom as mentioned in Negarakertagama, that the central government of Bali is in Badahulu near Lwah Gajah. It is no exaggeration to assume that Pura Samuan Tiga in the X century is a temple of upgrading and the ancient Balinese kingdom located at the center of government which in some local sources is called Bata Anyar.

Based on the description of tattoos Tatwa Siwa Purana will raise the question, whether the name of Samuan Tiga is a name from since its establishment? This is important because the naming of a thing according to Balinese tradition is usually associated with a specific purpose or to commemorate a very meaningful event in a life process. That based on the explanation Kutaca Kanda Dewa Purana Bangsul above shows that Pura Samuan Tiga is a meeting place and deliberation of religious figures during the reign of Gunapriya Dharmapatni and Udayana who managed to decide agreement for the application of the conception of Tri Murti through the formation of Pekraman Village with each Kahyangan Tiga. 
In the palm of the King of Purana written Mpu Kuturan in the arrangement of religious life can be concluded, that Samuan Tiga Temple that we know today has undergone a long history process and the development of temple structure in accordance with the demands of the times. The founding of this temple was originally as a temple of Penataran of the Old Balinese period, and then made a place of religious figures, especially Ciwa Budha and Bali Aga who successfully agreed on the application of Tri Murti concept in the life of Pekraman Village and household in Bali. This concept is socially as a unifying media for all people based on a sense of togetherness and form of bhakti, so that the realization of harmony in each village. So it can be said that Samuan Tiga Temple is the forerunner of the Village Pekraman and Kahyangan Tiga as the application of the concept of Tri Murti in Bali.

In the future according to the development of community life, the existence of Samuan Tiga Temple is the responsibility of King Gianyar. However, the responsibility is then transferred to the family Pastor to maintain and perform the ceremony at Samuan Tiga Temple through the results of temple income. Because the results of temple income is not adequate, the responsibility is then submitted to the community around 1963 which then formed a committee under the leadership of I Wayan Limbak. The congregation consists of 6 traditional villages or 12 Banjar, but as supporters consist of all Hindus wherever they are. This is because Pura Samuan Tiga as mentioned above as Kahyangan Jagat Temple, namely as the forerunner of Kahyangan Tiga Temple in every Pekraman Village and Mrajan in every family as a place of worship Dewa Tri Murti manifestation of Ida Sang Hyang Widhi Wasa.

4) Travel Attractions Tegallinggah Cliff Temple

Tegallinggah Cliff Temple tourist attraction is located in Banjar Tegallinggah, Bedulu Village, Blahbatuh District, Gianyar Regency. Candi Tegallinggah is astronomically located at the coordinate point $8^{\circ} 31^{\prime} 40.36 " \mathrm{~S}, 115^{\circ} 18^{\prime} 21.74 "$ E. To go to Tegallinggah must go through a small road near the turn that deviates to Kutri. Travel visitors to the Tegal Linggah Cliff Temple can be reached by down the stairs. Along the way down the stairs visitors will pass the fish pond, ground water source and rice fields. Beautiful natural landscape can remove the tired when down the stairs.

Access to tourist attraction is not well ordered. Streets and stones are slippery. When entering the temple area there are many large rocks that adorn. Tegallinggah Cliff Temple is separated by Pakerisan River. On the walls of the temple there are nineteen holes where the ascetic is done in antiquity. At this tourist attraction is also displayed gate of the temple right and left tied yellow white cloth that adds traditional Balinese characteristics. The beauty and uniqueness of the temple can be used as a place for tourists to take pictures, whether it is a photo of a holiday, pre wedding or shooting video clip.

Archaeologists find historical relics in the form of a temple in Banjar Tegallinggah. The temple, discovered by an archaeologist from the Netherlands named Krijsman, is thought to have been built in the XII century. At that time Krijsman was conducting an investigation by digging in a small building located in the Valley of Pakerisan River. The building is carved into the cliff wall and is only considered as an entrance gate by the local community. Gate the right has a larger shape, but unfortunately now the gate is only a ruin. While the gate on the left has a form like a semi-finished monastery that is estimated the monastery was not completed because of earthquake disaster, so had to be stopped. Seven fruit and three phallus are found in the temple. These phalluses depict the three main deities in Hinduism known as Tri Murti, namely Brahma, Vishnu, and Lord Shiva. Regency of Gianyar increase strong position as the center of ancient sites in Bali with the discovery of this Tegallinggah Cliff Temple.

\section{Activities in Bedulu Village}

1) Conducting a survey to identify all the potential tourism and culture in Bedulu village and surrounding areas to be compiled into a tourist guide book on information for local and tourist guides.

2) Training Package Cultural Tour Packages in Bedulu Village

3) Tour Guiding Technique Training in Bedulu Village

4) Creation of guidebooks of cultural tourism attraction in Bedulu Village in English. Book Guide Tour aims to provide complete information to tourists about tourist attraction located in Bedulu Village, promoting tourism promotion Bedulu Village, as well as facilitate tourists to get information about the location and description of tourist attractions in Bedulu village, such as Pura Goa Gajah, Yeh Pulu Relief, Samuan Tiga Temple, and Tegallinggah Cliff Temple. The Guide Book comes with information on the history, shrine, culture, home stay recommendations, specialty foods, and restaurants located at Bedulu Tourist Village. The result of making Guide Book will be distributed to hotels, restaurants and home stay around Gianyar regency. The purpose of making this guidebook is as follows: 1) Provide complete information to tourists about tourist attraction located in Bedulu Village, 2) Make it easier for tourists to get information about the history, location and information related to tourism activities located in Bedulu Village, 3) As a guide for local people who work as a local guide in Bedulu Village, 4) Making Bedulu Tourism Brochure 
As a tourist village, the challenge faced by Bedulu Village is the lack of optimum tourism promotion; so many tourists do not know the existence of tourist attraction in Bedulu village. Therefore it is necessary to empower the community and increase the intensification of tourism promotion Bedulu Village through brochures that will contain interesting information about the tourist attraction in the village Bedulu. The purpose this activity is: 1) Increasing the awareness of tourists, both local and foreign tourists to the tourist attraction contained in Bedulu Village, 2) Tourists know the tourism potential in Bedulu village, 3) As a guide for local people who work as a local guide in Bedulu Village.

6) Website Creation Bedulu Village

The Bedulu Village website contains textual information, images and videos for the purpose of facilitating access to information about tourist attractions in Bedulu Village and promoting Bedulu Village. The objectives of these training procurement activities are: 1) Make it easier to access information about the tourist areas in Bedulu Village, 2) Promote Desa Bedulu.

The process of obtaining information contained in the website is done in several different places, namely Goa Gajah Temple attraction, Yeh Pulu Relief, Pura Samuan Tiga, and Tegaling Tegalinggah Temple, and the area around the Village Bedulu. Then the process of website editing is done at Bedulu Village post located in Banjar Mas, Bedulu Village, Blahbatuh District, Gianyar Regency. In addition, Bedulu Village also prepared administrative tutorial of website management, so Bedulu Village Office staff can manage their own website as admin.

7) Practical English training for prospective local and youth guides in Bedulu Village

8) Record the homes of residents who are ready to be a place to stay for tourists (homestay) as well as Training of Bedroom Setting in Bedulu Village. The objectives of these training procurement activities are: 1) Those empower community skills and skills in homestay management to increase the active participation of local communities in tourism activities, 2) Find the potential and develop a homestay in Bedulu Village, 3) Develop new jobs to improve the living standards of local communities.

9) Culinary Training and Development of Bedulu Village

The objectives of these training procurement activities are: 1) Those empowering people's skills and skills in the field of culinary to improve community productivity, 2) Find the potential and develop culinary Bedulu Village, 3) Establish new jobs to improve people's lives.

10) Village Management Training Tour in Bedulu Village

11) Cooperation with travel agents in marketing tour packages in the village Bedulu. Cooperation is also conducted with the tourism industry in helping provide training to the community.

12) Making of Tourism Promotion Video of Bedulu Village Information technology plays a very important role in delivering messages in the form of text, pictures and sound to users around the world. Video is a combination of dead images that are read sequentially at a time with a certain speed. With the video, the process of communication and promotion of a product or a tourist area to the target market becomes easier and faster. The making of the video aims to promote the existing attractions in the village Bedulu becomes more interesting and easy to direct. The results obtained are a video that then uploaded to YouTube. Here is the YouTube link of the video https://youtu.be/KBNK1YWtVWs. A constraint during the process of making this video is a rather complicated video retrieval process considering so many places to go to get maximum results.

\section{Supporting Programs in Bedulu Village}

1) Procurement of Trash

Procurement of this waste is one of the auxiliary programs conducted in all elementary schools as Bedulu village and Yeh Pulu Relief Tourism Attraction. The purposes of this program are: 1) Teach children to be able to keep their environment clean by dumping garbage, 2) Maintain environmental cleanliness in Yeh Pulu Relief Tourism Attraction.

2) Manufacture and Installation of Yeh Pulu Relief Tour Directions

The lack of signposts makes it difficult to find tourist attractions Yeh Pulu Relief. Directions from the highway do not exist at all; while the signposts enter the path is just paint on the walls of the houses. Procurement signpost Yeh Pulu Relief tourist attraction is very important because it can provide information to tourists and very helpful when made trekking path through the tourist attraction and the Management of Tourism Object Relief Yeh Pulu

\section{Conclusions}

Activities in Bedulu Village, Blahbatuh District, Gianyar Regency aims to strengthen community empowerment through the development of cultural tourism in accordance with the vision of the Bedulu Village mission. In addition, this activity aims to strengthen the village management system, increase 
community participation in tourism activities and development, increase self-financing and self-help communities and to improve the welfare of the community and increase the original income of Gianyar regency. The problems encountered in the Bedulu Village are the lack of community involvement in village management and tourist attraction in the village, the lack of human resources and the weak understanding of the local community towards tourism potential and the potential of the culture. The approach model includes: 1) participatory rural appraisal (PRA) model; 2) entrepreneurship capacity building model (ECB); and 3) transfer technology model (TT).

To overcome the various problems mentioned above, some of the proposed activity plans in the implementation of the program in Bedulu Village, Blahbatuh District as follows: 11) Identification of tourism potential at Pura Goa Gajah Attraction, Relief Yeh Pulu, Pura Samuan Tiga, and Tegallinggah Cliff Temple; 2) Focus Group Discussion (FGD) potential and strategic issues of tourism development based on local wisdom culture in Bedulu Village; 3) Training of Packaging Cultural Tour Packages in Bedulu Village; 4) Technical Training for Tour Guide in Bedulu Village; 5) Making of Guide Book; 6) Making Bedouin Tourism Brochure; 7) Practical English Training in Bedulu Village; 8) Homestay Management Training in Bedulu Village; 9) Culinary Development Training of Bedulu Village; 10) Village Tourism Management in Bedulu Village. The resulting outputs in community service activities include: a guide book in English on tourism potentials located in Bedulu village and complemented by information about restaurants and homestays, as well as information accessible through social media instagram, video Uploaded to YouTube, as well as websites accessible to travelers. In addition, there are also brochures in English and Japanese which provide information on tourist attractions in the Bedulu village and trekking tracks that travelers can try, as well as information accessible through social media instagram, videos uploaded to YouTube, and Websites that can be accessed by tourists. This activity also produces tutorials on website management, so the community / village staff can keep updating the information on the website. Other outcomes are the improvement of people's knowledge and skills in terms of: packaging cultural tourism packages; Guided tour techniques; Practical English; Homestay management; Culinary development typical of Bedulu Village; As well as village tourism management in Bedulu Village. In the future, this activity is expected to continue and can be applied in order to provide benefits and improve the welfare of the community.

\section{Refrence}

Anonim. 2013. Profil Desa Bedulu, Gianyar-Bali.

----------. Undang-Undang Nomor 5 Tahun 1979 tentang Pemerintahan Desa.

. Peraturan Pemerintah Nomor 18 Tahun 1994 tentang Pengelolaan Alam di Zona

Pemanfaatan Kawasan Pelestarian Alam.

-. Undang-Undang Nomor 22 Tahun 1999 tentang Otonomi Daerah.

-. Undang-Undang Nomor 32 Tahun 2004 tentang Pemerintahan Desa.

----------. Undang-Undang Nomor 10 Tahun 2009 tentang Kepariwisataan.

----------. Undang-Undang Nomor 6 Tahun 2014 tentang Desa.

Ardika, I Wayan. 2003. Pariwisata Budaya Berkelanjutan: Refleksi dan Harapan di Tengah Perkembangan Global. Denpasar: Universitas Udayana.

Azam, Mehdi dan Tapan Sarker. 2011. Green Tourism in The Context of Climate Change Towards Sustainable Economic Development in The South Asian Region. Journal of Enviromental Management and Tourism. Vol 2(3), pp.6-15.

Badan Pusat Statistik (BPS) Provinsi Bali. 2016. Bali dalam Angka 2015. Badan Pusat Statistik Provinsi Bali Tahun 2016.

Cooper, Chris and Stephen Jackson. 1997. Destination Life Cycle: The Isle of Man Case Study. Dalam the Earthscan Reader in Sustainable Tourism. United Kingdom: Earthscan Publications Limited. 
Desky, M.A. 2001. Pengantar Bisnis Biro Perjalanan Wisata. Yogyakarta: Adicita Karya Nusa.

Dinas Pariwisata Propinsi Bali. 2016. Buku Direktori Pariwisata Bali. Denpasar.

Inskeep, Edward. 1991. Tourism Plannning “An Integrated and Sustainable Development Approach". New York: Van Nostrand Reinhold.

Kesrul, M. 2003. Penyelenggaraan Operasi Perjalanan Wisata. Jakarta: PT. Gramedia Widiasarana Indonesia.

Kodyat, H. 1997. "Hakekat dan Perkembangan Wisata Alternatif". Dalam Prosiding Pelatihan dan Lokakarya Perencanaan Pariwisata Berkelanjutan, ed. Myra P. Gunawan. Bandung: Penerbit ITB.

Korten, David. 1987. Community Management. New Delhi: Kumarian Press.

Marcini, Marc. 1996. Conducting Tours. Delmar Publishers an International Thomson Publishing Company.

Muhajir. 2005. Menjadi Pemandu Wisata Pemula. Jakarta: PT. Gramedia Widiasarana Indonesia.

Natori, Nasahiko (ed). 2001. A Guide Book for Tourism Based Community Development. Publisher APTE.

Nuryati, Windu. 1993. Concept, Perspektif and Challenges. International conference.

Pitana, I Gde. 1999. Pelangi Pariwisata Bali. Denpasar: Bali Post. Kepariwisataan.

Ringbeck, Jurgen, Amira El-Adawi, and Amit Gautam. 2010. Green Tourism: a Road Map for Transformation. Booz \& Company.

Soekadijo, R.G. 1997. Anatomi Pariwisata (Memahami Pariwisata Sebagai Systemic Linkage). Jakarta: Gramedia Pustaka Utama.

Suyitno. 2001. Perencanaan Wisata. Yogyakarta: Kanisius.

Wood, Megan Epler. 1999. Ecotourism, Principles, Practises and Policies for Sustainability. UNEO and TIES Publication.

Yoeti, Oka A. 1996. Pengantar Pariwisata. Edisi Revisi. Bandung: Angkasa.

2001. Tour and Travel Management. Jakarta: PT. Pradnya Paramita. 